\title{
A ploidy chimera reveals the effects of tetraploidy in date palm
}

\author{
A. Othmani ${ }^{1}$, M. Jemni' ${ }^{2}$, L. Leus ${ }^{3}$, A. Sellemi ${ }^{1}$, F. Artés ${ }^{4}$ and S. Werbrouck ${ }^{5}$ \\ ${ }^{1}$ Centre Régional de Recherches en Agriculture Oasienne, Laboratoire de Culture in vitro du Palmier Dattier, Degache, \\ Tunisia \\ ${ }^{2}$ Centre Régional de Recherches en Agriculture Oasienne, Laboratoire de Technologie des Dattes, Degache, Tunisia \\ ${ }^{3}$ Flanders Research Institute for Agriculture, Fisheries and Food (ILVO), Plant Sciences Unit, Melle, Belgium \\ ${ }^{4}$ Technical University of Cartagena, UPCT, Dept. Food Engineering, Postharvest and Refrigeration Group, Cartagena, Murcia, \\ Spain \\ ${ }^{5}$ Ghent University, Faculty of Bioscience Engineering, Dept. Plant \& Crops, Ghent, Belgium
}

\section{Summary}

In the oasis of Tozeur (Tunisia) a peculiar date palm ploidy chimera was discovered, showing a diploid $(2 n=2 x)$ and a tetraploid $(2 n=4 x)$ sector and a uniform tetraploid offshoot. This chimera allowed to describe the effects of chromosome doubling on some selected features. Because both ploidies occur within one plant, there was no environmental bias. Tetraploid leaves are longer, bear larger leaflets and spines and have a thicker rachis than normal diploid leaves. During three seasons, tetraploid inflorescences appeared ten days later than their diploid counterparts. The tetraploid sector formed bunches with stalks bearing larger fruits, with a higher percentage of inedible parthenocarpic fruits, than bunches that arose from the diploid sector. Tetraploid fruits are significantly longer, wider and heavier than diploid fruits, with a larger pulp diameter, irrespective of whether they are seeded or parthenocarpic. Diploid parthenocarpic fruits are longer than seeded fruits, while tetraploid parthenocarpic and seeded fruits both show the same size. The occurrence of tetraploidy opens new perspectives in date palm breeding. Pollination of tetraploid pistils with pollen from diploid males gave rise to a relatively low number of triploid plantlets, suggesting a triploid block.

Keywords

flow cytometry, flowering, parthenocarpy, phenology, Phoenix dactylifera, polyploidy

\section{Introduction}

For millennia, the oases at Tozeur and Kebili in southern Tunisia have served as an ideal environment for growing date palms. The area combines extreme high temperatures, intense sunlight and plenty of groundwater. Local farmers have gained valuable experience with more than 250 cultivars, which have been described by Rhouma (1994). Despite great in situ genetic biodiversity, the main cultivated variety is 'Deglet Noor'. Through offshoot propagation, 40,000 ha of this cultivar are currently being grown locally. The massive number of available trees (about 3.5 million) offers an ideal opportunity to discover interesting off-types. Recently, attentive farmers discovered a peculiar date palm with an offshoot that partially showed larger leaves and larger fruit than normal ones. Those fruits were either seeded or parthe-

\section{Significance of this study}

What is already known on this subject?

- Tetraploidy in palms in general is very rare. The effects in date palm were never described before.

What are the new findings?

- A lucky discovery of a date palm ploidy chimera which produced a uniform tetraploid offshoot allowed to describe the effects of chromosome doubling on leaves, inflorescences and fruits. Also the effects on parthenocarpic fruits, which are often produced after insufficient pollination, are treated.

What is the expected impact on horticulture?

- In the future, tetraploid male date palms must be either found or raised, because their pollen will likely lead to better fertilization of tetraploid flowers. This could lead to a higher yield of longer, wider and heavier fruits, with good organoleptic characteristics and a high phenolic content. These features make them very promising for worldwide markets.

nocarpic seedless. In date-producing areas today, parthenocarpic dates are not highly appreciated and are used as animal food. Polyploidy is rare in the palm family, except for the four species Arenga caudata, Rhapis humilis, Jubaeopsis caffra and Voanioala gerardii (Arunachalam, 2012). Tetraploidy induction in palms was restricted to oil palm, by applying colchicine and oryzalin to germinating seeds (Madon et al., 2005) or colchicine to secondary somatic embryos (Te-chato, 2012). The latter reported that tetraploid plantlets had thick, dark green leaves. The purpose of this research was first, to test the hypothesis that this plant is a ploidy sectorial chimera, and second, to use this spontaneous mutant and its attached offshoot to clarify the effect of chromosome doubling on leaf, fruit and seed morphology. Although Mason described a putative sectorial ploidy chimera in 1930, this is the first detailed report of a proven sectorial ploidy chimera and the effects of tetraploidy.

\section{Materials and methods}

\section{Tissue sampling}

In February and October 2016, leaflets and fruits from defined zones of the abnormal date palm of the variety 'Deglet Noor' (Figure 1) were sampled for ploidy measurements. 
Small and large leaflets were taken from the main trunk and large leaflets from its offshoot. Normal or large sized seeded (ripe) fruits were sampled from clearly defined sectors, as well as seedless (parthenocarpic) fruits from homogenous or mixed fruit stalks. Leaves were also taken from seedlings derived from seeds from standard and large fruits of the date palm. During transport, the tissues were conserved in polyethylene bags and kept fresh in a cool box under refrigeration for three days before ploidy analysis.

\section{Ploidy analysis}

Ploidy analysis was performed by means of flow cytometry (Leus et al., 2009) using a CyFlow Space (Sysmex, Münster, Germany) flow cytometer equipped with a UV Light Emitting Diode and Flomax 2.9 software (Quantum Analysis, Münster, Germany) to determine peak positions on the acquired histograms. Sample preparation involved chopping of leaf tissue (according to Galbraith et al., 1983) and sample preparation including 4', 6-diamidino-2-phenylindole (Sigma-Aldrich, Belgium) staining, according to Otto (1990). As a reference, standard leaf material of a diploid date palm was used. Three samples were examined per plant tissue (Table 1). A ploidy histogram of a co-chopped sample composed of a normal $(2 x)$ fruit, a leaf from a triploid seedling and a large ( $4 x$ ) fruit illustrates a clear peak separation (Figure 2).

\section{Morphological observation and measurements}

The emergence date of the inflorescences and the fruit maturation date of the two sectors of the studied date palm were noted during 2015, 2016 and 2017. Pictures were taken from the leaves, young inflorescences, rachis and fruit stalks of the main trunk and the offshoot.

Tetraploid, tetraploid/diploid, and uniform diploid leaves were cut from the basal crown. Following plant morphology parameters were monitored using a measuring tape and a sliding caliper: leaf length, thickness of the rachis and width of the palm at the base of the petiole, average number, maximum thickness and maximum length of the spines. For the apical leaflet, number, maximum thickness and maximum length of leaflets, length and width were measured. Fruit length, diameter and weight were measured, as well as pulp thickness and perianth diameter on 30 seeded or parthenocarpic fruits from diploid or tetraploid sectors. Seed length, diameter and weight were determined on 30 seeds of fruits from diploid or tetraploid sectors.150 Fruits from both diploid or tetraploid sectors were opened for examining the presence of seeds.

\section{Chemical analysis of fruits}

Sugar composition of date fruits was determined based on Aguayo et al. (2006), using an analytical HPLC (Merck Hitachi, Darmstadt, Germany) equipped with a refractive index detector (Hitachi, L-7490 model, Tokyo, Japan), L7100 pump, a Hitachi L7200 automatic sample injector and a LiChroCART 250-4 Purospher STAR NH 2 column (Merck, Darmstadt, Germany). Extracts were obtained from $10 \mathrm{~g}$ (f.w.) fruits grounded with a mortar in $50 \mathrm{~mL}$ of hot water at $100^{\circ} \mathrm{C}$. The homogenates were then centrifuged at $4^{\circ} \mathrm{C}$ for $10 \mathrm{~min}$ at $15,000 \times \mathrm{g}$ to obtain the extracts. A $20 \mu \mathrm{L}$ extract sample was injected using a mobile phase of 85:15 acetonitrile:water (Merck, Germany) at a $1.5 \mathrm{~mL} \mathrm{~min}^{-1}$ flow. The sucrose, glucose and fructose concentrations were determined by means of standards. Results were reported as g sugar $100 \mathrm{~g}^{-1}$ fresh weight (f.w.). All extracts were analyzed in triplicate.

To determine the total concentration of phenolics, fro- zen samples with liquid nitrogen (0.5 g) of fruit, grounded with a mortar, were diluted with $3 \mathrm{~mL} \mathrm{MeOH}$ and maintained in darkness and on ice for extraction during $1 \mathrm{~h}$ on a shaker. The homogenates were centrifuged at $4^{\circ} \mathrm{C}$ for $10 \mathrm{~min}$ at $15,000 \times g$ and the supernatant was used for further analysis. The amount of total phenolics was determined using the Folin-Ciocalteu reagent based on Artés-Hernández et al. (2010). Briefly, an aliquot of $19.2 \mu \mathrm{L}$ extract of the supernatant was mixed with $29 \mu \mathrm{L}$ of Folin-Ciocalteu reagent (1:10, $\mathrm{v} / \mathrm{v}$ diluted with MilliQ water) and $192 \mu \mathrm{L}$ sodium carbonate $(20 \%, \mathrm{w} / \mathrm{v})$. The mixture was incubated for $1 \mathrm{~h}$ at room temperature in darkness (without shaker). The extracts are centrifuged at $4^{\circ} \mathrm{C}$ for $10 \mathrm{~min}$ at $15,000 \times \mathrm{g}$ for clarification. Subsequently, absorption was measured at $750 \mathrm{~nm}$ (Hewlett Packard 8453, UV-vis spectrophotometer, Columbia MD USA). Total phenolic concentration was expressed as gallic acid equivalents (GAE) in $\mathrm{g} 100 \mathrm{~g}^{-1}$ f.w. All extracts were analyzed in triplicate.

The total antioxidant activity of the date fruits was assayed based on the evaluation of the free radical scavenging capacity, according to Artés-Hernández et al. (2010). A solution of $0.7 \mathrm{mM} \mathrm{2,2-diphenyl-1-picrylhydrazil} \mathrm{(DPPH)}$ was prepared $2 \mathrm{~h}$ before the assay. Its absorbance at $517 \mathrm{~nm}$ was adjusted to $1.1 \pm 0.02$. Immediately before using methanol, an aliquot of $21 \mu \mathrm{L}$ of the extracts obtained from the preparation of phenolic compounds was added to $194 \mu \mathrm{L}$ of this solution. The mixture was incubated in darkness at room temperature for $50 \mathrm{~min}$. The antioxidant activity was measured by decreasing the absorbance at $517 \mathrm{~nm}$ (Tecan Infinite M200, Männedorf, Switzerland). The results were expressed as g ascorbic acid equivalent antioxidant capacity (AEAC) per $100 \mathrm{~g}$ fresh weight. All measurements were made in triplicate.

\section{Color of leaflets}

For color monitoring, a color-difference meter (Minolta CR 300, Ramsey, NJ, USA) was used (C standard C.I.E. illumination, $0^{\circ}$ viewing), and the results were expressed as CIELAB color space units. The mean values for the lightness $(L)$, red/green coordinate $(a)$, and blue/yellow coordinate (b) parameters were calculated for large and normal leaflets at ten sites on their surface, according to CIE (1976).

\section{Hybridization}

In 2014, 2015 and 2016, flowers of the aberrant part of the main trunk were pollinated by Abd1, P7 and P8 males that were known for good fertility (Othmani et al., 2017). The method consisted of placing strands of male flowers of Abd1, P7 and P8 either apart or together between those of the female inflorescences. Male and female flowers were covered with 'craft' paper before anthesis until after pollination to avoid cross-pollination. In those three years, 3,515, 3,420 and 2,010 ripe fruits were harvested seven months after pollination. Germination of the obtained seeds required soaking them in a solution of sodium hypochlorite (20\%) for $24 \mathrm{~h}$ followed by transfer to an empty Petri dish containing three sterile filter paper disks soaked in water and placed in a culture room at $28 \pm 2{ }^{\circ} \mathrm{C}$ with $16 / 8 \mathrm{~h}$ photoperiod and $80 \mu \mathrm{mol}$ $\mathrm{m}^{-2} \mathrm{~s}^{-1}$ white fluorescent light for 3 weeks.

\section{Statistical analysis}

Except otherwise indicated, all parameters were determined on three samples. Averages of these three samples are presented. Statistical analysis was performed with SPSS (version 25). Analysis of variance (ANOVA) and Tukey's B 


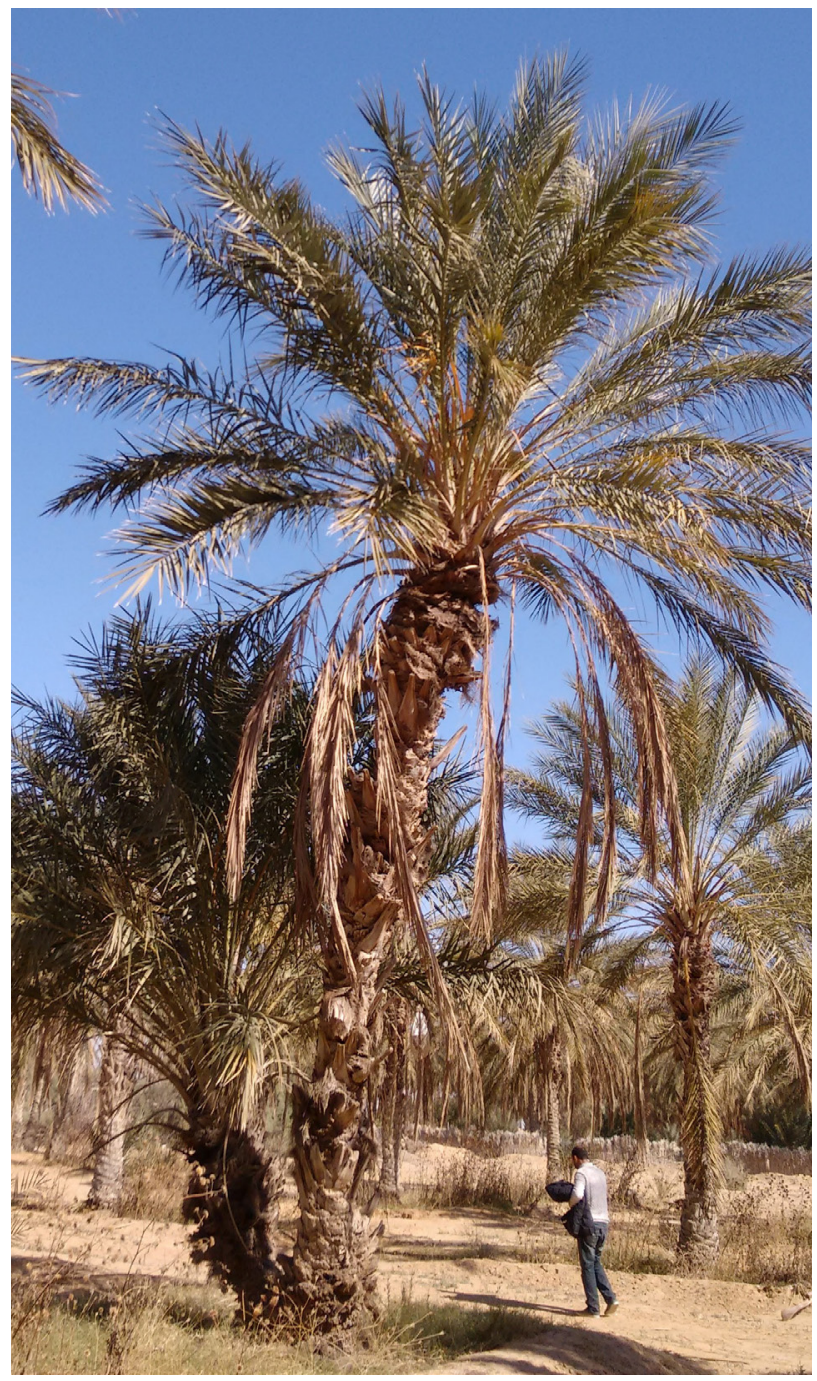

FIGURE 1. The aberrant date palm with a smaller off type offshoot at the left side.
TABLE 1. Ploidy level of the different zones of the date palm and its offshoot with altered phenotype.

\begin{tabular}{lc}
\hline Description & Ploidy $(2 n)$ \\
\hline Large leaf from the main trunk & $4 x$ \\
Normal sized leaf from the main trunk & $2 x$ \\
Normal sized fruit from the main trunk & $2 x$ \\
Normal sized parthenocarpic fruit from the main trunk & $2 x$ \\
$\begin{array}{l}\text { Normal edible fruit from the fruit stalk with mixed types } \\
\text { of fruits }\end{array}$ & $2 x$ \\
$\begin{array}{l}\text { Normal sized parthenocarpic fruit from the fruit stalk } \\
\text { with mixed types of fruits }\end{array}$ & $2 x$ \\
$\begin{array}{l}\text { Large edible fruit from the fruit stalk with mixed types } \\
\text { of fruits }\end{array}$ & $4 x$ \\
Large parthenocarpic fruit from the fruit stalk with mixed & $4 x$ \\
types of fruits & \\
Leaflet from off-shoot & $4 x$ \\
Fruit from off-shoot & $4 x$ \\
Leaf from a seedling issued from a large seed from & $3 x$ \\
a mixed fruit stalk & \\
Leaf from a seedling issued from a normal sized seed \\
from a mixed fruit stalk \\
$\begin{array}{l}\text { Leaf from a seedling issued from a normal seed from } \\
\text { the main trunk }\end{array}$ & $2 x$ \\
\hline
\end{tabular}

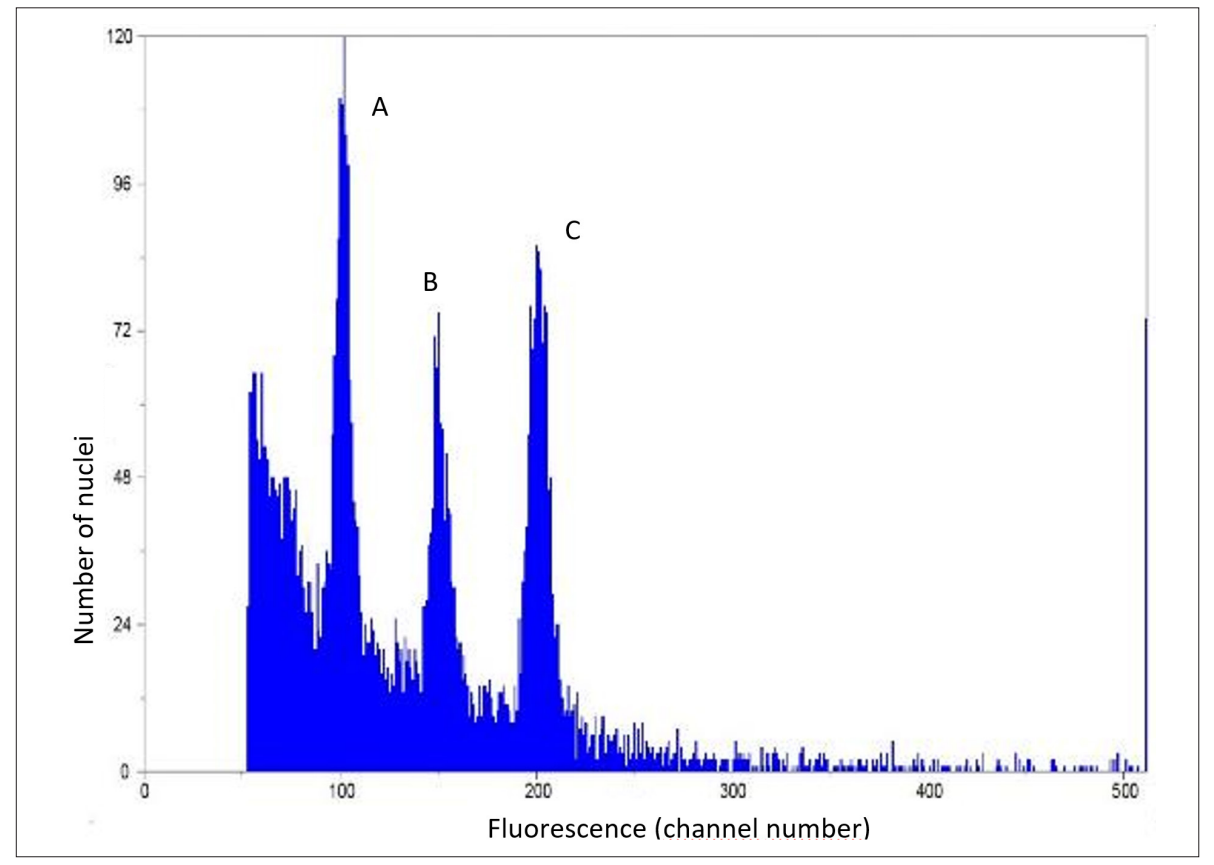

FIGURE 2. Ploidy histogram of a co-chopped sample composed of: (A) a normal $(2 x)$ fruit, (B) a leaf from a triploid seedling and (C) a large $(4 x)$ fruit, showing a clear peak separation. 


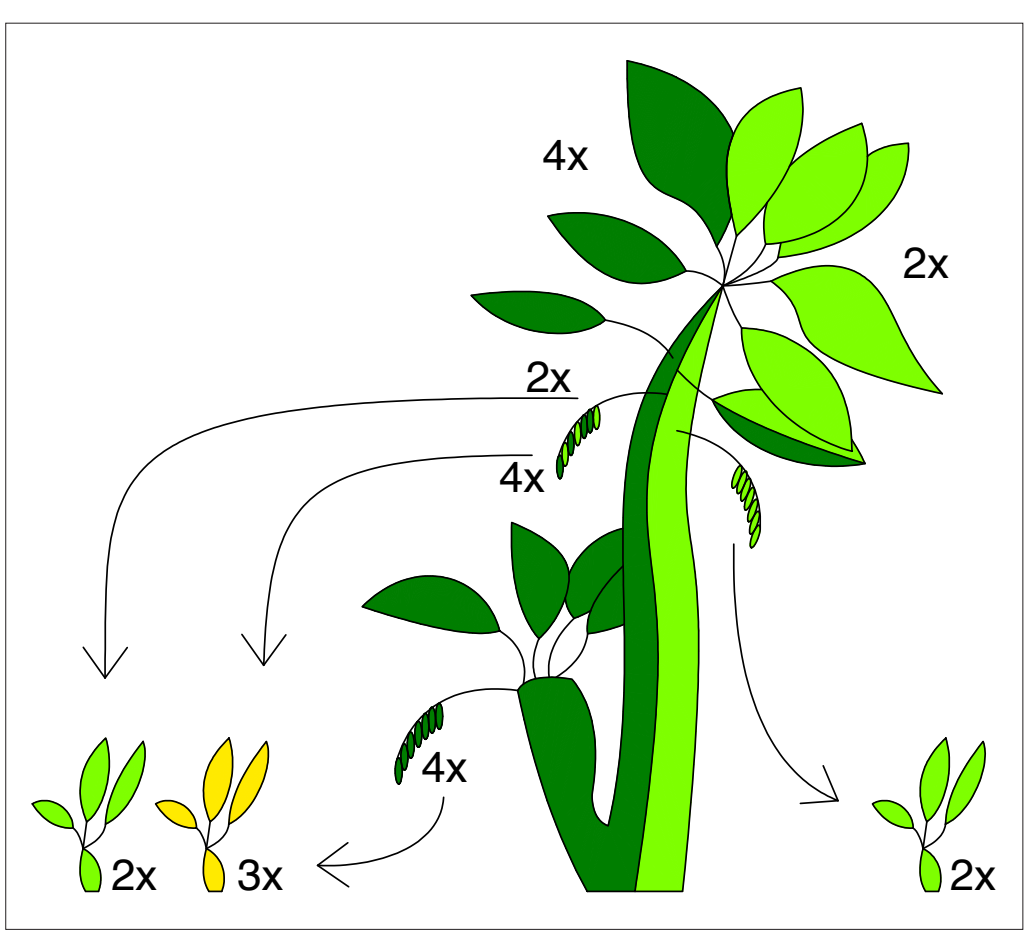

FIGURE 3. Schematic drawing of the ploidy of the different zones within the chimera (dark green $2 n=4 x$, light green $2 n=2 x$, yellow $2 n=3 x$ ). test $5 \%$ probability or independent-samples $t$-test $(5 \%)$ were applied in order to evaluate the influence of ploidy level on morphological and physicochemical parameters of date palm.

\section{Results}

\section{Ploidy analysis}

The results of the ploidy analysis are presented in Table 1 . The derived histogenic composition of the tree is schematized in Figure 3. The main shoot had a diploid and tetraploid sector characterized by diploid or tetraploid leaves and fruits. The offshoot was completely tetraploid. The normal sized fruits were diploid and the large ones were tetraploid. Further, mixoploid fruit stalks could be distinguished because they contained a combination of both normal diploid and larger tetraploid fruits. The large fruits contained small or large seeds. Only the large seeds germinated and they produced triploid seedlings. An embryo was lacking in the small seeds.

\section{Effect of ploidy doubling}

Tetraploid leaves are longer, bear larger leaflets and spines and have a thicker rachis than the diploid leaves. The mixoploid leaves show two different halves, showing either large or normal leaflets and spines. Parameters of normal, large/normal and large leaves are presented in Table 2. Color parameters of normal and large leaflets are provided in Table 3. The ploidy level had no significant effect on luminosity. The values for parameter $a$ and $b$ indicate that tetraploid leaflets were darker green and more blue than diploid leaflets.

During three successive years, tetraploid inflorescences appeared $11.7 \pm 1.8$ days later than the diploid equivalents and tetraploid fruit maturation initiated $10.3 \pm 1.1$ days later than diploid fruit. Tetraploid flowering stems have a round section, in contrast with the ellipsoid sector of diploid flowering stems. The mixoploid flowering stem consists of two different colored sectors. The ellipsoid diploid sector is characterized by a lemon yellow color; the round tetraploid sector is more greenish.

TABLE 2. Morphological parameters of diploid, mixoploid and tetraploid leaves.

\begin{tabular}{lrr}
\hline Leaves & Diploid & Mixoploid \\
\hline Leaf length $(\mathrm{cm})$ & $375.2 \mathrm{a}$ & $379.7 \mathrm{a}$ \\
Thickness of the rachis $(\mathrm{cm})$ & $2.6 \mathrm{a}$ & $3.5 \mathrm{~b}$ \\
Leaf width at the base of the petiole $(\mathrm{cm})$ & $23.8 \mathrm{a}$ & $36.6 \mathrm{~b}$ \\
Average number of spines & $3.9 \mathrm{c}$ & $25.9 \mathrm{a}$ \\
Maximum thickness of spines $(\mathrm{cm})$ & $0.61 \mathrm{a}$ & $31 \mathrm{a}$ \\
Maximum length of spines $(\mathrm{cm})$ & $21.4 \mathrm{a}$ & $1.23 \mathrm{~b}$ \\
Number of leaflets (pens) & $149 \mathrm{c}$ & $23.8 \mathrm{~b}$ \\
Maximum width of leaflets in the middle of the palm $(\mathrm{cm})$ & $1.4 \mathrm{a}$ & $139 \mathrm{~b}$ \\
Maximum length of the leaflets in the middle of the palm $(\mathrm{cm})$ & $56.2 \mathrm{a}$ & $2.2 \mathrm{~b}$ \\
Length of the apical leaflet $(\mathrm{cm})$ & $33.6 \mathrm{a}$ & $129 \mathrm{~b}$ \\
Width of the apical leaflet $(\mathrm{cm})$ & $1.3 \mathrm{a}$ & $56.5 \mathrm{a}$ \\
\hline
\end{tabular}

Within one row, means followed by the same letter are not significantly different (Tukey $5 \%$ ). 
TABLE 3. Color parameters of leaflet (CIELAB: $L$ : lightness, $a$ : red/green coordinate and $b$ : blue/yellow coordinate). Data are expressed as means $(n=3)$. Means with different letters are significantly different $(\mathrm{p} \leq 0.05)$ according to the independent-samples $t$-test (5\%).

\begin{tabular}{lccc}
\hline Leaf type & $L$ & $a$ & $b$ \\
\hline Diploid leaflet & $46.61 \mathrm{a}$ & $-11.28 \mathrm{a}$ & $14.83 \mathrm{a}$ \\
Tetraploid leaflet & $47.92 \mathrm{a}$ & $-10.35 \mathrm{~b}$ & $18.15 \mathrm{~b}$ \\
\hline
\end{tabular}

Within one column, means followed by the same letter are not significantly different: independent-samples t-test $(5 \%)$.

Three types of fruit bunches were formed. The diploid sector gave rise to bunches bearing normal sized fruits. The tetraploid sector formed bunches with larger fruits and the mixoploid sector a mixed bunch type (Figure 4A). Both normal sized diploid and large tetraploid fruits were either seeded or parthenocarpic. The flowers of the $2 x$ sector were usually well pollinated and produced normal sized seeded fruits. The majority of the tetraploid fruits however, was parthenocarpic. Fruit morphology is illustrated in Figure 4B-D and parameters of fruits and seeds taken from diploid and tetraploid bunches are presented in Table 4. Tetraploid fruits were significantly longer, wider and heavier than diploid fruits, with a larger pulp diameter, irrespective of wheth- er they were seeded or parthenocarpic. Parthenocarpic tetraploid fruits were longer than seeded tetraploid fruits and had a larger perianth. For diploid fruits this was only the case for the perianth length. Seeded fruits were always heavier but didn't necessarily have a larger fruit pulp diameter. In fact, tetraploid parthenocarpic fruits had more pulp than tetraploid seeded fruits, despite a lower total weight. The seeds of diploid fruits had a larger diameter and were heavier than seeds from tetraploid fruits. Sugar and total concentrations and antioxidant activity of edible normal and large fruits are presented in Table 5. Tetraploid seeded fruits contained more of the monosaccharides glucose and fructose, while their diploid counterparts held four times more sucrose. Moreover, polyphenols were slightly higher in tetraploid fruits.

\section{Triploid offspring}

The majority of the fruits (99\%) produced by the tetraploid plant part, after being pollinated with the pollen of the diploid males, was parthenocarpic. As a result, the fruits were inedible and their seeds were small and infertile. The tetraploid offshoot did also produce a limited number of edible fruits. Only $34 \%$ of them contained normal seeds, of which $66 \%$ germinated. Finally, an average of $0.28 \%$ of all fruits produced by the $4 x$ offshoot yielded triploid plants. No tetraploid plants were recorded.

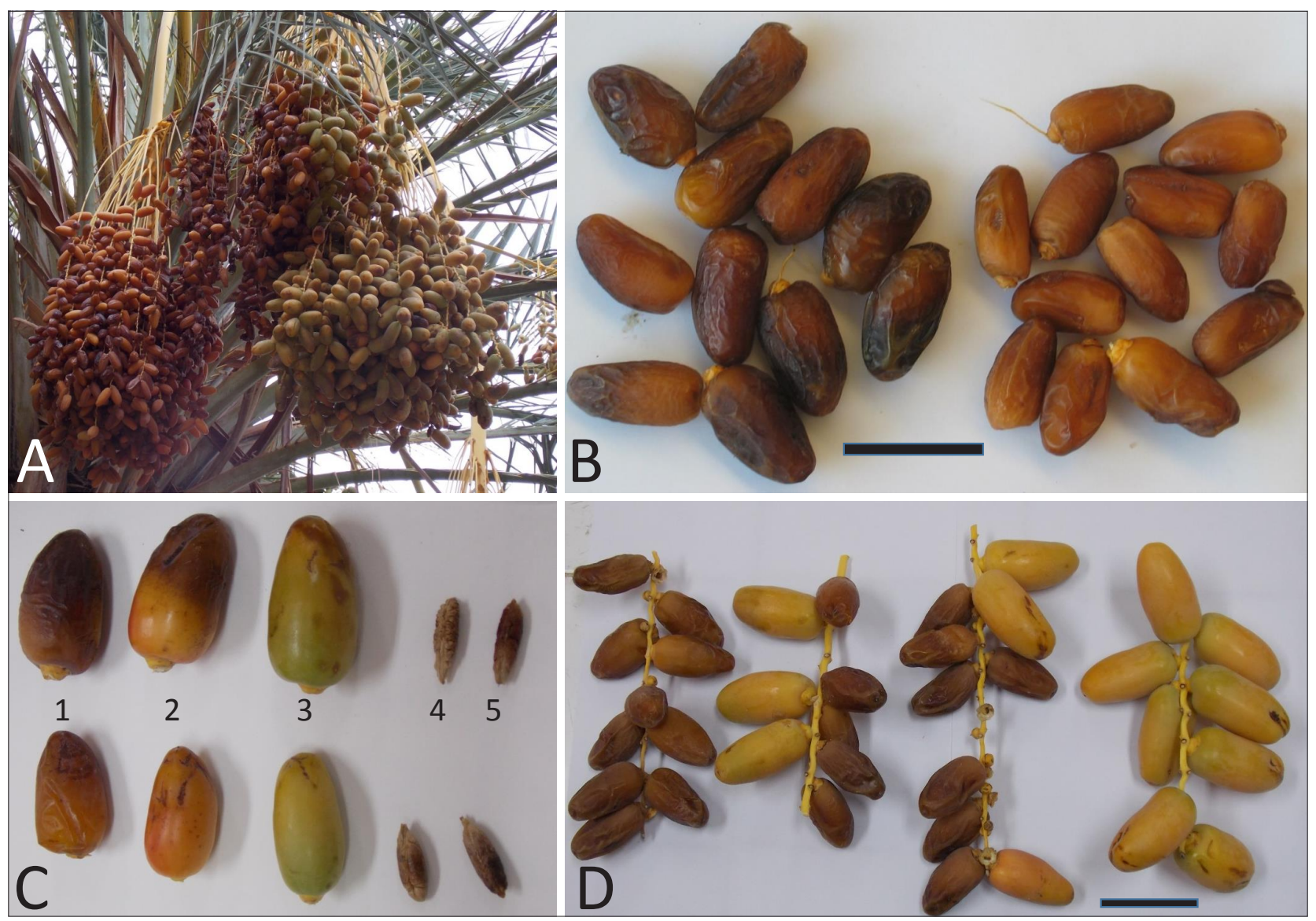

FIGURE 4. Fruit bunch and fruits. A: Left: fruit bunch with uniform seeded brown $2 x$ fruits; right: mixoploid bunches with $4 x$ parthenocarpic green and $2 x$ seeded brown fruits. B: Seeded $4 x$ (left) and $2 x$ (right) fruits at 'tamar' stage (bar $=5 \mathrm{~cm}$ ). C: Morphology of different fruit and seed forms produced by the date palm chimera (top: $4 x$ and bottom: $2 x$ ). (1) seeded fruits at 'tamar' = ripe stage; (2) seeded fruits at 'khalal' stage (start ripening); (3) parthenocarpic fruits; (4) seed ventral side; and (5) seed dorsal side. D: Fruit stalks bearing uniform normal edible (left), uniform large inedible (right) and mixed normal edible and large inedible fruits (middle two) (bar $=5 \mathrm{~cm})$. 
TABLE 4. Parameters of diploid and tetraploid seeded (edible) and parthenocarpic (inedible) fruits and their seeds.

\begin{tabular}{lcccccccc} 
& $\begin{array}{c}\text { Fruit } \\
\text { length } \\
(\mathrm{cm})\end{array}$ & $\begin{array}{c}\text { Fruit } \\
\text { diameter } \\
(\mathrm{cm})\end{array}$ & $\begin{array}{c}\text { Fruit } \\
\text { weight } \\
(\mathrm{g})\end{array}$ & $\begin{array}{c}\text { Pulp } \\
\text { thickness } \\
(\mathrm{cm})\end{array}$ & $\begin{array}{c}\text { Perianth } \\
\text { diameter } \\
(\mathrm{cm})\end{array}$ & $\begin{array}{c}\text { Seed } \\
\text { length } \\
(\mathrm{cm})\end{array}$ & $\begin{array}{c}\text { Seed } \\
\text { diameter } \\
(\mathrm{cm})\end{array}$ & $\begin{array}{c}\text { Seed } \\
\text { weight } \\
(\mathrm{g})\end{array}$ \\
\hline Seeded $2 x$ fruits & $4.0 \mathrm{a}$ & $1.6 \mathrm{a}$ & $12.9 \mathrm{~b}$ & $0.37 \mathrm{a}$ & $0.52 \mathrm{a}$ & $2.2 \mathrm{a}$ & $0.37 \mathrm{~b}$ & $0.87 \mathrm{~b}$ \\
Parthenocarpic 2 x fruits & $4.1 \mathrm{a}$ & $1.8 \mathrm{~b}$ & $6.1 \mathrm{a}$ & $0.41 \mathrm{ab}$ & $0.89 \mathrm{~d}$ & - & - & - \\
Seeded 4x fruits & $4.4 \mathrm{~b}$ & $2.1 \mathrm{c}$ & $17.9 \mathrm{~d}$ & $0.45 \mathrm{~b}$ & $0.66 \mathrm{~b}$ & $2.4 \mathrm{~b}$ & $0.29 \mathrm{a}$ & $0.61 \mathrm{a}$ \\
Parthenocarpic $4 x$ fruits & $5.0 \mathrm{c}$ & $2.2 \mathrm{c}$ & $15.5 \mathrm{c}$ & $0.62 \mathrm{c}$ & $0.77 \mathrm{c}$ & - & - & - \\
\hline
\end{tabular}

Within one column, means followed by the same letter are not significantly different: fruit parameters: Tukey (5\%), seed parameters: independentsamples $t$-test $(5 \%)$.

TABLE 5. Concentration of sugar and total polyphenols and antioxidant activity of seeded (edible) diploid and tetraploid fruits (g 100 g $^{-1}$ f.w.).

\begin{tabular}{lccccc}
\hline Fruit & Total sugars & Glucose & Fructose & Sucrose & $\begin{array}{c}\text { Total polyphenols } \\
\left(\mathrm{mg} \mathrm{GAE} \mathrm{100} \mathrm{g}^{-1}\right)\end{array}$ \\
\hline Seeded $2 x$ & $35.83 \mathrm{a}$ & $7.92 \mathrm{a}$ & $8.68 \mathrm{a}$ & $19.23 \mathrm{~b}$ & $52.32 \mathrm{a}$ \\
Seeded $4 x$ & $29.52 \mathrm{a}$ & $11.35 \mathrm{a}$ & $13.06 \mathrm{a}$ & $5.11 \mathrm{a}$ & $67.13 \mathrm{~b}$ \\
\hline
\end{tabular}

Within one column, means followed by the same letter are not significantly different: independent-samples $t$-test ( $5 \%)$.

\section{Discussion}

\section{Ploidy chimera}

Taking into account the results reported above, this particular phenotypic variant of date palm is a ploidy chimera. Flow cytometry (Dolezel et al., 2007; Leus et al., 2009) proved to be a suitable and fast method to determine the ploidy level, even of hard leaves and ripe, partly dried fruits. Ploidy measurements were related to the morphology of leaves, flower stalks, fruit bunches and fruits. This chimera is composed of a diploid and a tetraploid sector which extend longitudinally alongside one another. The diploid sector represented the morphological characteristics of the 'Deglet Noor' date palm. The tetraploid sector has specific morphological characteristics that were also observed in the uniform tetraploid offshoot.

A careful inspection of this plant allows an educated guess about the origin and nature of this special plant that, several years ago, also started as an off-shoot. The relatively large tetraploid sector suggests that a spontaneous chromosome doubling happened at a very young developmental stage; it was probably situated in the meristem when it was forming an axillary bud at the base of the mother plant. Hence, while developing into an offshoot, the tetraploid sector was already present. The young chimera was separated from the mother plant using classical clonal propagation and was subsequently rooted and planted. The tetraploid sector occupies about the half of the meristem and extends through all cell layers. The two sectors managed to maintain their identity during many years of coexistence. Even now the apical shoot tip very likely contains both cell lines. A new sucker originated from the tetraploid sector. It is uniformly tetraploid and can be used for further cloning of $100 \%$ tetraploid 'Deglet Noor'. The chimera itself cannot be propagated. This would require offshoots that originate from two cells which each belong to one of the layers, an extremely rare event. Spontaneous induction of polyploids in the meristematic as well as non-meristematic tissue through mitotic polyploidization has been also reported in several plant species as reviewed by Comai (2005) and Soltis et al. (2015).

\section{Effect of tetraploidy}

Beal (1937) described the chromosome numbers of both male and female date palms as being identical, $2 n=36$. Ouarda et al. (2014) examined genome size in the Tunisian cultivars of $P$. dactylifera. They concluded that all are diploid, with a mean DNA content between 1.73 and $1.80 \mathrm{pg} / 2 \mathrm{C}$. Although Salman et al. (1988) described a case of polyploidization in micropropagated date palm, naturally occurring polyploidy and its effects have never been studied or previously reported in date palm (Al-Ani, 2010). Our results show that tetraploid date leaves are longer, bear larger leaflets and spines and have a thicker rachis than the diploid leaves. Diploid flower stalks have an ellipsoid transversal sector, colored lemon yellow, while the tetraploid flower stalks have a round transversal sector and are more greenish in color. These features are easily observed. They contrast with oil palm where leaves of tetraploid plantlets were actually shorter and relatively wider than diploid plantlets (Te-chato, 2012). Tetraploid date fruits are significantly longer, wider and heavier than diploid fruits, irrespective of whether they are seeded or parthenocarpic. Seeded fruits are always heavier but do not have a larger fruit pulp diameter. The seeds of diploid fruits have a larger diameter and are heavier than seeds from tetraploid fruit containing a triploid embryo. The change of morphological characteristics caused by an altered ploidy level is common in other plant species, as described for example in apple (Hias et al., 2017), Spathiphyllum wallisii (Van Laere et al., 2011), Hydrangea macrophylla (Keri et al., 2007), Lilium spp. (Okazaki and Hane, 2005) and plantain and banana (Vandenhout et al., 1995). Larger fruit sizes have been observed in tetraploid Vitis spp. (Notsuka et al., 2000) and Chaenomeles japonica (Stanys et al., 2006). The tetraploid offshoot appeared to be more robust and developed greater biomass and larger organs than the diploid mother plant. These characteristics could be attributed to the larger number of gene copies (Sattler et al., 2016). This result is consistent with the observations made by Stebbins (1950) and Ye et al. (2010), who found that polyploidization generally increases cell size and leaf area. However, increased size is not always observed in all organs of tetraploid plants. For in- 
stance, in tetraploid apple plants, leaf length and size were less than observed in diploid counterparts, which could be correlated to their lower cell density (Hias et al., 2017). Tetraploid date inflorescences appeared $11.7 \pm 1.8$ days later than their diploid counterparts and tetraploid fruit maturation was initiated $10.3 \pm 1.1$ days later. Okazaki and Hane (2005) reported that differences in ploidy could have a clear impact on physiological traits. Tetraploid leaflets are greener and more bluish than diploid leaflets. Similarly, Allario et al. (2011) noted that in citrus, tetraploid leaves are darker green, which could be explained at least partially by their higher pigment concentration.

\section{Parthenocarpy}

After fertilization, tetraploid dates are edible and contain triploid seeds. But fertilization by diploid pollen was rarely successful, leading to an overwhelming majority of parthenocarpic fruits. This finding has been confirmed in some other species, e.g., in grape, were the number of seedless berries increases as the ploidy level rises from diploid to tetraploid (Sarikhani and Wakana, 2009). Sattler et al. (2016) proposed that this is caused by meiotic errors, resulting in seed abortion and seedless fruit development. Parthenocarpy is a problem, not because of the lack of seeds, but because of the retarded ripening and poor pulp taste. In date-producing areas today, parthenocarpic dates are not highly appreciated and are given to animals as fodder. Remarkably, among the dates found at Tutankhamun's tomb, a significant proportion of them were parthenocarpic fruits, leading to the hypothesis that these may have been appreciated as food in ancient Egypt (Terral et al., 2012).

\section{Triploid plants}

Triploid plants were obtained after hybridization of a diploid egg cell $(n=2 x)$ of the tetraploid sector and a pollen nucleus $(n=x)$ of the diploid males with a very low frequency. The endosperm supports development of the embryo and is crucial for viable seed formation. In particular, deviations from the ratio of one paternal to two maternal genomes can cause endosperm failure and a triploid block (Köhler et al., 2010). The morphology of the obtained triploid date palm will be studied further while they continue to grow and start to flower. Especially the occurrence of seedless triploid fruits and their characteristics and consumption quality will be important to examine.

\section{Conclusion and prospects}

This female ploidy chimera enabled, for the first time, to describe the effects of chromosome doubling in date palm. Tetraploid plant parts such as leaves, flower stalks, and fruits can easily be recognized by their larger size and distinctive color. The failure of fertilization of tetraploid female flowers by pollen of diploid father plants leads to parthenocarpic fruits of low quality. Nevertheless, a limited number of triploid seeds could be harvested and the obtained seedlings will permit further analysis. In the future, tetraploid male date palms must be either found or raised, because their pollen will likely lead to better fertilization of tetraploid flowers. This could lead to a higher yield of large-seeded fruits with good organoleptic characteristics and taste, and a higher phenolic content.

\section{Acknowledgments}

The authors acknowledge Dr. Ahmed Namsi for his competent and valuable comments and suggestions during the execution of this work, and special thanks go to Miriam Levenson (ILVO) for the careful English language review.

\section{References}

Aguayo, E., Escalona, V.H., and Artés, F. (2006). Effect of cyclic exposure to ozone gas on physicochemical, sensorial and microbial quality of whole and sliced tomatoes. Postharvest Biol. Technol. 39, 169-177. https://doi.org/10.1016/j.postharvbio.2005.11.005.

Al-Ani, B., Zaid, A., and Shabana, H. (2010). On the status of chromosomes of the date palm (Phoenix dactylifera L.). Acta Hortic. 882, 253-268. https://doi.org/10.17660/ActaHortic.2010.882.28.

Allario, T., Brumos, J., Colmenero-Flores, J.M., Tadeo, F., Froelicher, Y., Talon, M., Navarro, L., Ollitrault, P., and Morillon, R. (2011). Large changes in anatomy and physiology between diploid Rangpur lime (Citrus limonia) and its autotetraploid are not associated with large changes in leaf gene expression. J. Experim. Botany 62, 2507-2519. https://doi.org/10.1093/jxb/erq467.

Artés-Hernández, F., Robles, P.A., Gómez, P., Tomás-Callejas, A., and Artés, F. (2010). Low UV-C illumination for keeping overall quality of fresh-cut watermelon. Postharvest Biol. Technol. 55, 114-120. https://doi.org/10.1016/j.postharvbio.2009.09.002.

Arunachalam, V. (2012). Genomics of Cultivated Palms (London: Elsevier), 114 pp. https://doi.org/10.1016/B978-0-12-3877369.00004-2.

Beal, J.M. (1937). Cytological studies in the genus Phoenix. Botanical Gazette 99, 400-407. https://doi.org/10.1086/334708.

Comai, L. (2005). The advantages and disadvantages of being polyploid. Nature Rev. Genetics 6(11), 836. https://doi.org/10.1038/ $\operatorname{nrg} 1711$.

Dolezel, J., Greilhuber, J., and Suda, J. (2007). Flow cytometry with plants: an overview. In Flow Cytometry with Plant Cells, J. Dolezel, J. Greilhuber, and J. Suda, eds. (Weinheim: Wiley), p. 41-65. https:// doi.org/10.1002/9783527610921.ch3.

Galbraith, D.W., Harkins, K.R., Maddox, J.M., Ayres, N.M., Sharma, D.P., and Firoozabady, E. (1983). Rapid flow cytometric analysis of the cell cycle in intact plant tissues. Science 220, 1049-1051. https:// doi.org/10.1126/science.220.4601.1049.

Hias, N., Leus, L., Davey, M.W., Vanderzande, S., Huylenbroeck, J.V., and Keulemans, J. (2017). Effect of polyploidization on morphology in two apple (Malus $\times$ domestica) genotypes. Hort. Sci. 44, 55-63. https://doi.org/10.17221/7/2016-HORTSCI.

Keri, D., Reed, S.M., and Rinehart, T.A. (2007). Analysis of ploidy level and its effects on guard cell length, pollen diameter, and fertility in Hydrangea macrophylla. Hortscience 42(3), 483-488. https://doi. org/10.21273/HORTSCI.42.3.483.

Köhler, C., Scheid, O.M., and Erilova, A. (2010). The impact of the triploid block on the origin and evolution of polyploid plants. Trends in Genetics 26(3), 142-148. https://doi.org/10.1016/j. tig.2009.12d.006.

Leus, L., Van Laere, K., Dewitte, A., and Van Huylenbroeck, J. (2009). Flow cytometry for plant breeding. Acta Hortic. 836, 221-226. https://doi.org/10.17660/ActaHortic.2009.836.31.

Madon, M., Clyde, M.M., Hashim, H., Mohd, Y., Mat, H., and Saratha, S. (2005). Polyploidy induction of oil palm through colchicine and oryzalin treatments. J. Oil Palm Res. 17, 110-123.

Marks, G.E. (1966). The origin and significance of intraspecific polyploidy: Experimental evidence from Solanum chacoense. Evolution 20, 552-557. https://doi.org/10.1111/j.1558-5646.1966. tb03385.x.

Mason, S.C. (1930). A sectorial mutation of a Deglet Noor date palm. J. Heredity 21(4), 157-163. https://doi.org/10.1093/oxfordjournals. jhered.a103309. 
Notsuka, K., Tsuru, T., and Shiraishi, M. (2000). Induced polyploid grapes via in vitro chromosome doubling. J. Jpn. Soc. Hortic. Sci. 69, 543-551. https://doi.org/10.2503/jjshs.69.543.

Okazaki, K., and Hane, Y. (2005). Comparison of diploid and chimeric forms $(4 x / 2 x)$ of Asiatic hybrids lilies (Lilium spp.) under natural and early forcing culture. N. Z. J. Crop Hortic. Sci. 33, 261-267. https:// doi.org/10.1080/01140671.2005.9514358.

Othmani, A., Collin, M., Sellemi, A., Jain, S.M., Drira, N., and Aberlenc, F. (2017). First reported case of spontaneous hermaphrodism in female date palm (Phoenix dactylifera L.), cv 'Alligue'. J. Hortic. Sci. Biotechnol. 92(4), 376-388.

Otto, F.J. (1990). DAPI staining of fixed cells for high-resolution flow cytometry of nuclear DNA. Meth. Cell Biol. 33, 105-110. https://doi. org/10.1016/S0091-679X(08)60516-6.

Ouarda, H.E.F., Walker, D.J., and Khouja, M.L. (2014). Phenotypic and nuclear DNA variation in Tunisian cultivars of date palm (Phoenix dactylifera L.). African J. Biotechnol. 11(22), 6034-6042.

Rhouma, A. (1994). Le palmier dattier en Tunisie. Le patrimoine génétique. (INRA de Tunisie). PNUD/FAO/RAB/88/024.

Salman, M., Al-Jibouri, M., Al-Quadhy, K., and Omar, S. (1988). Isozyme and chromosomal analysis of tissue culture derived date palms. Date Palm J. 6, 401-411.

Sarikhani, H., and Wakana, A. (2009). Effect of ploidy on parthenocarpy in grape cultivars. Acta Hortic. 827, 433-438. https:// doi.org/10.17660/ActaHortic.2009.827.74.

Sattler, M.C., Carvalho, C.R., and Clarindo, W.R. (2016). The polyploidy and its key role in plant breeding. Planta 243, 281-296. https://doi. org/10.1007/s00425-015-2450-X.

Soltis, P.S., Marchant, D.B., Van de Peer, Y., and Soltis, D.E. (2015). Polyploidy and genome evolution in plants. Current Opin. Genetics \& Developm. 35, 119-125. https://doi.org/10.1016/j. gde.2015.11.003.

Stanys, V., Wechman, A., Staniene, G., and Duchovskis, P. (2006). In vitro induction of polyploidy in Japanese quince (Chaenomeles japonica). Plant. Cell Tissue Org. Cult. 84, 263-267. https://doi. org/10.1007/s11240-005-9029-3.

Stebbins, G.L. (1950). Variation and Evolution in Plants (London: Geoffrey Cumberlege). https://doi.org/10.7312/steb94536.

Te-chato, S.S.S. (2012). Ploidy induction through secondary somatic embryo (SSE) of oil palm by colchicine treatment. J. Agric. Technol. 8(1), 337-352.

Terral, J.F., Newton, C., Ivorra, S., Gros-Balthazard, M., de Morais, C.T., Picq, S., Tengberg, M., and Pintaud, J.C. (2012). Insights into the historical biogeography of the date palm (Phoenix dactylifera L.) using geometric morphometry of modern and ancient seeds. J. Biogeography 39(5), 929-941. https://doi.org/10.1111/j.13652699.2011.02649.x.

Van Laere, K., França, S.C., Vansteenkiste, H., Huylenbroeck, J.V., Steppe, K., and Van Labeke, M.C. (2011). Influence of ploidy level on morphology, growth and drought susceptibility in Spathiphyllum wallisii. Acta Physiol. Plant. 33(4), 1149-1156. https://doi. org/10.1007/s11738-010-0643-2.

Vandenhout, H., Ortiz, R., Vuylsteke, D., Swennen, R., and Bai, K.V. (1995). Effect of ploidy on stomatal and other quantitative traits in plantain and banana hybrids. Euphytica 83(2), 117-122. https://doi. org/10.1007/BF01678038.

Ye, Y.M., Tong, J., Shi, X.P., Yuan, W., and Li, G.R. (2010). Morphological and cytological studies of diploid and colchicine induced tetraploid lines of crape myrtle (Lagerstroemia indica L.). Sci. Hortic. 124, 95101. https://doi.org/10.1016/j.scienta.2009.12.016.
Received: Oct. 12, 2018

Accepted: Oct. 18, 2019

Addresses of authors:

Ahmed Othmani ${ }^{1}$, Monia Jemni ${ }^{2}$, Leen Leus ${ }^{3}$, Amel Sellemi ${ }^{1}$,

Francisco Artés ${ }^{4}$ and Stefaan Werbrouck ${ }^{5}$

${ }^{1}$ Centre Régional de Recherches en Agriculture Oasienne, Laboratoire de Culture in vitro du Palmier Dattier,

62, 2260 Degache, Tunisia

${ }^{2}$ Centre Régional de Recherches en Agriculture Oasienne, Laboratoire de Technologie des Dattes, 62, 2260 Degache, Tunisia

${ }^{3}$ Flanders Research Institute for Agriculture, Fisheries and Food (ILVO), Plant Sciences Unit, Caritasstraat 39, 9090 Melle, Belgium

${ }^{4}$ Technical University of Cartagena, UPCT, Dept. Food Engineering, Postharvest and Refrigeration Group, Paseo

Alfonso XIII, 48, 30203 Cartagena, Murcia, Spain

${ }^{5}$ University Ghent, Belgium, Faculty of Bioscience Engineering, Dept. Plant \& Crops, Valentin Vaerwyckweg 1, 9000 Ghent, Belgium 